\title{
ДЕЯКІ АСПЕКТИ МОДИФІКАЦІї СПОСОБУ ЖИТТЯ НА ОСНОВІ ДІЄТИЧНИХ ПІДХОДІВ ПРИ КАРДІОРЕАБІЛІТАЦІЇ ХВОРИХ НА ІШЕМІЧНУ ХВОРОБУ СЕРЦЯ ТА ПІСЛЯ ОПЕРАЦІЙ НА СЕРЦІ
}

\author{
○Н. В. Пасєчко, Л. В. Радецька, П. П. Кузів, Н. І. Ярема, А. О. Боб, І. В. Смачило, \\ 3. П. Мандзій, А. І. Хоміцька, І. П. Савченко, Л. В. Наумова, Т. І. Крицький, М. Є. Гаврилюк \\ ДВНЗ «Тернопільський державний медичний університет імені І. Я. Горбачевського»
}

PЕзЮМЕ. На сьогодні в усьому світі розвиваються реабілітаційні програми, відзначається тенденція до їх індивідуалізації, включення нових методів, розширення показань для їх призначення. Це дозволяє ширше і ефективніше застосовувати можливості відновної медицини. Вивчивши типи інтервального голодування ми застосували просту і безпечну схему харчування хворих на ішемічну хворобу серця (IXC) з застосуванням методу обмеження «вікна харчування".

Мета роботи - підвищити ефективність кардіореабілітації хворих на IXC та після операцій на серці шляхом використання методу обмеження «вікна харчування», обґрунтувати доцільність його застосування.

Матеріал і методи. Обстежено 54 хворих на IXC та після операцій на серці віком від 42 до 71 року. У 78,3 \% пацієнтів захворювання поєднувалось з супутніми хворобами (гіпертонічна хвороба, аліментарне ожиріння, компенсований цукровий діабет II типу тощо). Усі пацієнти отримували стандартне медикаментозне лікування відповідно до діагнозу, згідно з останніми клінічними рекомендаціями. Клінічну ефективність даного виду реабілітації та фармакологічних засобів оцінювали з урахуванням частоти та інтенсивності нападів стенокардії, ЧСС, АТ, даних ЕКГ у спокої і в умовах динамічного навантаження. При проведенні навантажувального тесту враховували величину порогового динамічного навантаження, розраховували подвійний добуток. У динаміці (на початку та через 6-12 місяців спостереження) досліджували біохімічними методами показники ліпідного обміну, коефіцієнт атерогенності.

Результати. При застосуванні тривалого періоду обмеження «вікна харчування» (6-12 місяців) при кардіореабілітації хворих спостерігають позитивну динаміку гемодинамічних показників, підвищення толерантності до фізичних навантажень, нормалізацію параметрів ліпідного профілю крові.

Висновок. Обґрунтована доцільність застосування даного методу в комплексі профілактичних, лікувальних та реабілітаційних заходів у хворих на IXC та після перенесених операцій на серці.

КЛючовІ СлОВА: кардіореабілітація; ішемічна хвороба серця; гемодинаміка; ліпідний обмін; «вікно харчування».

Вступ. У розвинутих країнах щорічно зменшується захворюваність та смертність від серцево-судинних захворювань на 2,5-3 \% [1]. Таких результатів вдалось досягти завдяки впровадженню на державному рівні комплексних програм, які включають профілактичні заходи і реабілітацію. На сьогодні беззаперечна ефективність реабілітаційних програм після інфаркту міокарда, операцій на серці та, у ряді випадків, при IXC як альтернатива черезшкірним коронарним втручанням. При цьому відзначені сприятливе співвідношення вартість/ефективність і високий ступінь безпечності програм фізичних тренувань. Так, в США використання програми кардіореабілітації дозволяє зекономити від 2193 до 28193 доларів США на рік життя одного пацієнта [1]. Ці дані стали приводом для розширення показань для проведення кардіореабілітації в реабілітаційних центрах. Проте, якщо фізичні навантаження $\epsilon$ ключовим компонентом реабілітаційних програм, то питання оптимального харчування цієї категорії хворих залишається відкритим і зводиться лише до порад лікаря типу «схуднути» або «обмежити вживання жирів».
Вивчивши типи інтервального голодування ми застосували просту і безпечну схему харчування хворих на IXC за методом обмеження «вікна харчування». Його наукове обґрунтування пов'язане з відкриттям механізмів автофагії японським вченим Йосінорі Осумі (Yoshinori Ohsumi), який став Лауреатом Нобелівської премії з фізіології та медицини в 2016 році [2]. Клітина має два способи позбутися біологічного «сміття». По-перше, вона може скористатися величезними молекулами убіквітин-протеази - ферменту, який здатен розщеплювати білки на окремі амінокислоти. Протеази вільно плавають в цитоплазмі. Осумі досліджував другий спосіб - розщеплення «сміття» в лізосомах - автофагоцитоз. Суть його в наступному: спочатку клітина секвеструє молекули, визначені для знищення, вибудовуючи навколо них мембрану. Створюється квазіорганела з інкорпорованою в неї молекулою чи навіть іншою органелою - автофагосомою. Потім автофагосома зближується з лізосомою, утворюючи автолізосому. Всередині неї ізольований об'єкт потрапляє під дію гідролаз - ферментів, які розчиняють його. Автофагія - нормальна частина життєвого 
Огляди літератури, оригінальні дослідження, погляд на проблему, ювілеї

циклу клітини. Вона забезпечує виживання клітини при голодуванні, робить можливими диференціювання клітин і контроль росту, а також бере участь в регулюванні багатьох інших процесів у клітині [2-5]. Суть роботи проф. Й. Осумі проста: коли ми певний час голодуємо, клітини переробляють усе старе й непотрібне і омолоджуються.

Клінічний вплив голодування на організм людини широко досліджений і апробований на 1123 пацієнтах протягом 20 років професором ДВНЗ «Тернопільський державний медичний університет ім. І. Я. Горбачевського» Кузівим П. П. та його школою, у працях яких описані аутолітичний, гемодинамічний, клінічний та інший ефекти різних термінів голодування $[6,7]$.

Отже, вивчивши типи інтервального голодування ми пропонуємо просту і безпечну схему харчування, яка допомагає активувати процеси аутофагії, продовжити тривалість та покращити якість життя хворого. Суть методу полягає у наступному. Час, впродовж якого ми їмо, називається «вікном харчування». Та людина, яка встає о 7 годині і снідає через годину, відкриває "вікно" о 8 годині ранку. Якщо вечеря відбувається з 20 до 22 години, то “вікно" розтягується до 12-14 годин щодня. Враховуючи активність автофагії при голодуванні організму, «вікно харчування» рекомендували скоротити до 8-10 годин, що, власне, допоможе активувати аутофагію.

Мета роботи - підвищити ефективність кардіореабілітації хворих на IXC та після операцій на серці шляхом використання методу обмеження «вікна харчування", обґрунтувати доцільність його застосування.

Матеріал і методи дослідження. Під спостереженням перебували 54 хворих, серед яких 43 зі стабільною стенокардією II-III ФК, 22 - з постінфарктним кардіосклерозом (9 перенесли черезшкірне кардіоваскулярне втручання). Серед цих хворих артеріальну гіпертензію мали 45 пацієнтів. Аритмії діагностовано у 23 хворих: екстрасистолії - у 15, AV-блокаду I ст. - у 2, блокаду лівої або правої ніжок пучка Гіса - у 16, фібриляцію передсердь - у 24 пацієнтів. 13 хворих перенесли оперативне втручання з приводу фіброкальцинозу клапанів. Ознаки хронічної серцевої недостатності І стадії спостерігали у 11 пацієнтів, II-А стадії - у 35, ІІ-Б стадії - у 8 обстежених. Усі досліджені були віком від 42 до 71 року.

Діагноз верифіковано на ґрунті вивчення скарг, анамнезу захворювання та життя, результатів об'єктивного огляду, додаткових клініко-лабораторних та інструментальних методів обстеження. У 78,3 \% пацієнтів захворювання тривало більше трьох років, поєднувалось з супутніми хво- робами (аліментарне ожиріння, компенсований цукровий діабет II типу тощо).

Усі пацієнти отримували стандартне медикаментозне лікування відповідно до діагнозу, згідно з останніми рекомендаціями Європейського товариства кардіологів та Американської асоціації серця, та дотримувались рекомендацій положень Середземноморської дієти, яка вважається найефективнішою для профілактики IXC.

Групу контролю склали 15 пацієнтів, які відмовились обмежити «вікно харчування», тривалість їх часу харчування становила більше 13 годин.

Клінічну ефективність даного виду реабілітації та фармакологічних засобів оцінювали з урахуванням частоти та інтенсивності нападів стенокардії, кількості спожитих таблеток нітрогліцерину протягом доби, показників частоти серцевих скорочень (ЧСС), артеріального тиску (АТ), даних ЕКГ в спокої і в умовах динамічного навантаження. При проведенні навантажувального тесту враховувалась величина порогового динамічного навантаження, розраховувався подвійний добуток.

У динаміці (на початку та через 6 місяців спостереження) досліджували біохімічними методами показники ліпідного обміну, коефіцієнт атерогенності - за формулою А. М. Климова (1983).

Статистична обробка результатів проведена на комп'ютері за допомогою пакета прикладних програм з обчисленням критерію імовірності Стьюдента.

Результати й обговорення. В усіх обстежених хворих, які обмежили "вікно харчування" до 8-9 годин, аналіз клінічної картини в процесі реабілітації показав позитивну динаміку. Вже до 1015 дня у них покращувався настрій, з'являлося відчуття бадьорості, покращувався сон, підвищувався загальний життєвий тонус.

У групі обстежуваних (хворі на стенокардію II, III ФК) виражений клінічний ефект отримано у 42 хворих. Через 6 місяців реабілітації суттєво зменшилися частота та вираженість нападів стенокардії за добу (від $(2,26 \pm 0,22)$ до $(1,09 \pm 0,13)(р<0,05))$, у 7 хворих вони повністю припинились. Достовірно знижувався офісний АТ у пацієнтів із стенокардією та гіпертонічною хворобою (систолічний АТ від $(162,2 \pm 2,5)$ на початку реабілітації до $(128,2 \pm$ 1,6) мм рт.ст. після 6 місяців спостереження, діастолічний АТ - відповідно від $(99,6 \pm 2,8)$ до $(84,1 \pm 3,1)$ мм рт. ст.).

Паралельно підвищувалася толерантність до фізичного навантаження: величина порогового динамічного навантаження зросла з $(76,9 \pm 6,9)$ на початку лікування до $(95,7 \pm 7,5)$ Вт через 6 місяців ( $<<0,05)$, величина подвійного добутку на висоті навантаження відповідно зросла від $(197,5 \pm 17,5)$ до $(245,7 \pm 18,8)$ ум. од. $(p<0,05)$. 
Огляди літератури, оригінальні дослідження, погляд на проблему, ювілеї

Аналізуючи динаміку зміни маси тіла хворих у процесі реабілітації виявлено, що на початку дослідження вона становила в середньому $(90,81 \pm$ $1,79)$ кг, а через 6 місяців спостереження, маса тіла знизилася до $(80,69 \pm 1,67)$ кг $(p<0,001)$, тобто на $(10,11 \pm 0,38)$ кг $(11,14 \%)$. В загальному за 6-12 місяців спостереження середня втрата маси тіла складала $(9,52 \pm 1,98)$ кг ( $<<0,001)$.

У результаті аналізу показників ліпідного профілю крові у хворих на стабільну стенокардію І ФК (1 група) виявлено, що в обстежених до лікування достовірно були підвищені рівні загального холестерину (ЗХC), холестерину низької щільності (ХС ЛПНЩ), тригліцеридів (ТГ), коефіцієнт атерогенності (KА), порівняно з нормальними показниками. У процесі лікування візначалося зниження 3 ХС $3(5,78 \pm 0,16)$ до $(4,38 \pm 0,12)$ ммоль/л, $(p<0,05)$. Рівень ХС лПНЩ через 6 місяців реабілітації знизився, порівняно з початком, з $(4,21 \pm 0,20)$ до $(2,63 \pm 0,14)$ ммоль/л $(p<0,05)$. При аналізі динаміки тригліцеридів виявлена тенденція до зниження їх рівня, порівняно з початком реабілітації. Динаміка показників холестерину високої щільності (ХС лПВЩ) була недостовірною, проте част-

\section{ЛІТЕРАТУРА}

1. Сумин А. Н. Вопросы кардиохирургической реабилитации в материалах Международного конгресса EUROPREVENT 2008 (Париж, Франция, 1-3 мая 2008 г.) / А. Н. Сумин // Кардиология и сердечно-сосудистая хирургия. - 2008. - № 6. - Р. 24-30.

2. Yoshinori Ohsumi. Autophagy from beginning to end / Yoshinori Ohsumi // J. Cell Biol. -2012. - Vol. 16, 197 (2). P. 164-165.

3. George A. Soultoukis and Linda Partridge dietary protein, metabolism, and aging / A. George // Annu. Rev. Biochem. - 2016. - Vol. 85. - P. 5-34. Access provided by Columbia University on 02/27/18.

4. Autophagy: How does it Work? / Claudia Puri, Avraham Ashkenazi, Mariella Vicinanza [et al.] // Annu. Rev. Biochem. - 2016. - Vol. 85. - P. 685-713. Access provided by Columbia University on 02/27/18. C.686-805.

\section{REFERENCES}

1. Sumin, A.N. (2008). Voprosy kardiokhirurgicheskoy reabilitatsii v materialakh Mezhdunarodnogo kongressa EUROPREVENT 2008 (Parizh, Frantsiya, 1-3 maya 2008 g.) [Questions of cardiosurgical rehabilitation in the materials of the International Congress EUROPREVENT 2008 (Paris, France, 1-3 May 2008)]. Kardiologiya i serdechno-sosudistaya khirurgiya - Cardiology and Heart and Vessel Surgery, 6, 24-30 [in Russian].

2. Yoshinori, Ohsumi (2012). Autophagy from beginning to end. J. Cell Biol.,197 (2), 164-165. ка ХС ЛПВЩ в ЗХС збільшувалась $3(13,43 \pm 1,48)$ на початку дослідження до $(16,84 \pm 1,32) \%$ через 6-12 місяців ( $<<0,05)$. При аналізі коефіцієнта атерогенності привертало увагу достовірне його зниження наприкінці дослідження.

Висновки. 1. Доведена доцільність застосування обмеження "вікна харчування" при IXC 3 метою підвищення якості життя, нормалізації гемодинамічних показників та ліпідного спектра крові.

2. Реабілітація має бути використана в комплексі з методами профілактики та медикаментозного лікування. Тільки безпосередня участь пацієнтів у кардіореабілітації підвищує їх тривалу прихильність до модифікації способу життя.

Перспективи подальших досліджень. Для підвищення ефективності реабілітації та корекції факторів ризику IXC при проведенні первинної профілактики, а також у групах підвищеного ризику при проведенні вторинної профілактики, в умовах практичної охорони здоров'я доцільно ширше і ефективніше використовувати різні види дієтотерапії, враховуючи особисту прихильність хворого.

5. Persynaki A. Unraveling the metabolic health benefits of fasting related to religious beliefs: a narrative review / A. Persynaki, S. Karras, C. Pichard // Nutrition. -2017.Vol. 35. - P. 14-20. https://doi.org/10.1016/j.nut.2016.10. 005 .

6. Кузів П. П. Теоретичні та прикладні аспекти застосування розвантажувально-дієтичної терапії в поєднанні з гірудотерапією у хворих на ішемічну хворобу серця / П. П. Кузів, Л. В. Радецька // Екологічна фізіологія. - 2000. - № 2. - С. 18-24.

7. Динаміка клінічної симптоматики та гемодинамічних показників хворих із серцево-судинною патологією в процесі розвантажувально-дієтичної терапії / П. П. Кузів, Л. В. Радецька, Ю. І. Сливка, Ю. Ю. Дерпак [та ін.] //У зб.: Здобутки клінічної та експериментальної медицини. - Тернопіль. - 1999. - Вип. 4. - С. 123-126.

3. George, A. (2016). Soultoukis and Linda Partridge dietary protein, metabolism, and aging. Annu. Rev. Biochem., 85, 5-34. Access provided by Columbia University on $02 / 27 / 18$.

4. Carla, F. Bento, Maurizio Renna, Ghita Ghislat, Claudia Puri, Avraham Ashkenazi, Mariella Vicinanza, Fiona M. Menzies, \& David C. Rubinsztein. (2016). Mammalian Autophagy: How does it work? Annu. Rev. Biochem., 85, 685-713. Access provided by Columbia University on 02/27/18. C.686-805. . 
Огляди літератури, оригінальні дослідження, погляд на проблему, ювілеї

5. Persynaki, A., Karras, S., \& Pichard, C. (2017). Unraveling the metabolic health benefits of fasting related to religious beliefs: a narrative review. Nutrition, 35, 14-20. https://doi.org/10.1016/j.nut.2016.10. 005.

6. Kuziv, P.P., Radetska, L.V. (2000). Teoretychni ta prykladni aspekty zastosuvannia rozvantazhuvalno-diietychnoi terapii v poiednanni z hirudoterapiieiu u khvorykh na ishemichnu khvorobu sertsia [Theoretical and applied aspects of the application of discharging and diet therapy in combination with hirudotherapy in patients with coronary heart disease]. Ekolohichna fiziolohiia - Ecological Physiology, 2, 18-24 [in Ukrainian].
7. Kuziv, P.P., Radetska, L.V., Slyvka, Yu.I., Derpak, Yu.Yu., Naumova, L.V., Tiurina, V.F., Yarema, N.Z., \& Trotsiuk, V.R. (1999). Dynamika klinichnoi symptomatyky ta hemodynamichnykh pokaznykiv khvorykh iz sertsevo-sudynnoiu patolohiieiu v protsesi rozvantazhuvalno-diietychnoi terapii [Dynamics of clinical symptomatology and hemodynamic parameters of patients with cardiovascular pathology in the process of handling and dietary therapy]. $U$ zb.: Zdobutky klinichnoi ta eksperymentalnoi medytsyny-In Select. Achievements of Clinical and Experimental Medicine, 4. Ternopil [in Ukrainian]

\section{НЕКОТОРЫЕ АСПЕКТЫ МОДИФИКАЦИИ ОБРАЗА ЖИЗНИ НА ОСНОВЕ ДИЕТИЧЕСКИХ ПОДХОДОВ ПРИ КАРДИОРЕАБИЛИТАЦИИ БОЛЬНЫХ ИШЕМИЧЕСКОЙ БОЛЕЗНЬЮ СЕРДЦА И ПОСЛЕ ОПЕРАЦИЙ НА СЕРДЦЕ}

ОН. В. Пасечко, Л. В. Радецкая, П. П. Кузив, Н. И. Ярема, А. О. Боб, И. В. Смачило, 3. П. Мандзий, А. И. Хомицкая, И. П. Савченко, Л. В. Наумова, Т. И. Крицкий, М. Е. Гаврилюк ДВНЗ «Тернопольский государственный медицинский университет имени И. Я. Горбачевского»

РЕЗЮмЕ. В настоящее время во всем мире происходит развитие реабилитационных программ, отмечается тенденция к их индивидуализации, включение новых методов, расширение показаний для их назначения. Это позволяет шире и эффективнее применять возможности восстановительной медицины. Изучив типы интервального голодания мы применили простую и безопасную схему питания больных с ишемической болезнью сердца (ИБС) с применением метода ограничения «окна питания».

Цель работы - повысить эффективность кардиореабилитации больных ИБС и после операций на сердце путем использования метода ограничения «окна питания», обосновать целесообразность его применения.

Материал и методы. Обследовано 54 больных ИБС и после операций на сердце в возрасте от 42 до 71 года. У 78,3 \% пациентов заболевание сочеталось с сопутствующими болезнями (гипертоническая болезнь, алиментарное ожирение, компенсированный сахарный диабет II типа и др.). Все пациенты получали стандартное медикаментозное лечение согласно диагнозу, в соответствии с клиническими рекомендациями. Клиническую эффективность данного вида реабилитации и фармакологических препаратов оценивали с учетом частоты и интенсивности приступов стенокардии, ЧСС, АД, данных ЭКГ в покое и в условиях динамической нагрузки. При проведении нагрузочного теста учитывали величину пороговой динамической нагрузки, рассчитывали двойное произведение. В динамике (в начале и через 6-12 месяцев наблюдения) исследовали биохимическими методами показатели липидного обмена, коэффициент атерогенности.

Результаты. Установлено, что при применении длительного периода ограничения «окна питания» (6-12 месяцев) при кардиореабилитации больных наблюдаются положительная динамика гемодинамических показателей, повышение толерантности к физическим нагрузкам, нормализация параметров липидного профиля крови.

Вывод. Обоснована целесообразность применения данного метода в комплексе профилактических, лечебных и реабилитационных мероприятий у больных ИБС и после перенесенных операций на сердце.

КЛЮчЕВЫЕ СЛОВА: кардиореабилитация; ишемическая болезнь сердца; гемодинамика; липидный обмен; «окно питания".

\section{SOME ASPECTS OF MODIFICATION OF THE LIFE METHOD ON BASIS OF DIAGNOSTIC APPROACHES IN CARDIAC REHABILLITATION OF PATIENTS WITH ISCHEMIC HEART DISEASE AND AFTER HEART SURGERIES}

@N. V. Pasiechko, L. V. Radetska, P. P. Kuziv, N. I. Yarema, A. O. Bob, I. V. Smachilo, Z. P. Mandzii, A. I. Homitska, I. P. Savchenko, L. V. Naumova, T. I. Krytskyy, M. Ye. Gavryliuk

\section{Horbachevsky Ternopil State Medical University}

SUMMARY. At present, rehab programs are being developed around the world, there is a tendency towards their individualization and inclusion of new methods, expansion of impressions for their appointment. This allows for a wider and more efficient use of rehab medicine. Having studied the types of intermittent fasting, we have applied a simple and safe scheme of food for patients with coronary artery disease using the method of limiting "eating window". 
Огляди літератури, оригінальні дослідження, погляд на проблему, ювілеї

The aim of the work - to increase the efficiency of cardiac rehabilitation of patients with coronary heart disease and after heart surgery by using the method of restricting the "eating window", to substantiate the expediency of its application.

Material and Methods. 54 patients with coronary heart disease and after cardiac surgery aged 42 to 71 years were studied. In $78.3 \%$ of patients the disease was combined with concomitant illnesses (alimentary obesity compensated by type II diabetes, etc.). All patients received standard medical treatment according to the diagnosis, according to clinical recommendations. Clinical efficacy of this type of rehabilitation and pharmacological agents was evaluated taking into account the frequency and intensity of angina attacks, heart rate, blood pressure, ECG data at rest and in conditions of dynamic loading. When carrying out a load test, the value of the threshold dynamic load was taken into account, a double product was calculated. In dynamics (in the beginning and after 6-12 months of observation) biochemical methods of lipid metabolism, an atherogenicity coefficient were studied.

Results. It was established that in applying a long period of restriction of the "eating window" (6-12 months) during cardiac rehabilitation of patients there is a positive dynamics of hemodynamic parameters, increased tolerance to physical activity, normalization of parameters of the lipid profile of the blood.

Conclusion. The expediency of using this method in the complex of prophylactic, medical and rehabilitation measures in patients with coronary heart disease and postoperative operations on the heart is substantiated.

KEY WORDS: cardiac rehabilitation; ischemic heart disease; hemodynamics; lipid metabolism; "eating window".

Отримано 14.08.2018 